\title{
Solvent-induced virus inactivation by acidic arginine solution
}

\author{
KAZUKO TSUJIMOTO $^{1}$, MISAO UOZAKI ${ }^{1}$, KEIKO IKEDA ${ }^{1}$, HISASHI YAMAZAKI ${ }^{1}$, \\ HIROTOSHI UTSUNOMIYA ${ }^{2}$, MASAO ICHINOSE ${ }^{3}$, A. HAJIME KOYAMA ${ }^{1}$ and TSUTOMU ARAKAWA ${ }^{4}$ \\ ${ }^{1}$ Division of Virology, Department of Cellular and Molecular Medicine, ${ }^{2}$ Department of Strategic Surveillance \\ for Functional Food and Comprehensive Traditional Medicine, ${ }^{3}$ Department of Second Internal Medicine, \\ Wakayama Medical University Graduate School of Medicine, Wakayama 641-8509, Japan; \\ ${ }^{4}$ Alliance Protein Laboratories, 3957 Corte Cancion, Thousand Oaks, CA 91360, USA
}

Received August 12, 2009; Accepted October 5, 2009

DOI: 10.3892/ijmm_00000362

\begin{abstract}
Viral clearance is a primary concern for parenteral protein biopharmaceuticals. Low $\mathrm{pH}$, detergent/solvent wash, or heating, called pasteurization, has been the main process for virus inactivation. Detergent/solvent wash is also used to treat superficial infectious diseases, including herpes simplex virus (HSV) infections. Herein we examined virus inactivation effects of acidic arginine on HSV type 2 (HSV-2) as a function of $\mathrm{pH}$ and temperature in an attempt to find solvent conditions that are effective for virus inactivation, yet are compatible with in vivo applications. Aqueous arginine at $0.7 \mathrm{M}$ was highly effective on HSV-2, more so at lower $\mathrm{pH}$ and higher temperature. Its effects were stronger than $0.1 \mathrm{M}$ citrate, $0.1 \mathrm{M}$ citrate $/ 0.6 \mathrm{M} \mathrm{NaCl}$ or $0.7 \mathrm{M}$ citrate at any $\mathrm{pH}$ and temperature. This demonstrates that strong virus inactivation effects of arginine are not simply due to ionic strength or high concentration and arginine possesses a unique property that results in irreversible damage in virus particles. Such strong virus inactivation effects can be used in vivo for certain superficial infectious diseases, such as genital infections.
\end{abstract}

\section{Introduction}

Viral safety is critical in development of parenteral protein biopharmaceuticals $(1,2)$. Low $\mathrm{pH}$, detergent/solvent wash, or moderate heating, called pasteurization, has been the main process for virus inactivation $(1,2)$. Thus, there is consistent

Correspondence to: Dr A. Hajime Koyama, Division of Virology, Department of Cellular and Molecular Medicine, Wakayama Medical University Graduate School of Medicine, Wakayama 641-8509, Japan

E-mail: koyama@wakayama-med.ac.jp

Dr Tsutomu Arakawa, 3957 Corte Cancion, Thousand Oaks, CA 91360, USA

E-mail: tarakawa2@aol.com

Key words: solvent, virus inactivation, arginine, herpes simplex virus, temperature need for more effective inactivation technologies. Solvents have been used to manipulate physical properties of proteins in aqueous solutions (3-8). All the virus particles consist of proteins, lipids (for enveloped viruses) and nucleic acids. Thus, it is possible that solvents can alter the stability of viruses through their effects on these viral components. We have shown before that arginine, one of the natural amino acids, enhances virus inactivation at acidic $\mathrm{pH}$ condition on ice $(9,10)$ or elevated temperature at neutral $\mathrm{pH}(11,12)$. This study further investigates the effects of different solvents on the virus inactivation as a function of $\mathrm{pH}$ and temperature. We have used as a model virus herpes simplex virus, type-2, (HSV-2), responsible for genital herpes infection (13). Such a solvent-induced virus inactivation at elevated temperatures may find applications for virus clearance of not only pharmaceutical formulations but also superficial virus infections involving, e.g., HSV-2. In fact, detergent/solvent wash has been used to treat superficial infectious diseases (13).

\section{Materials and methods}

Materials. L-Arginine hydrochloride (simply described as arginine) was obtained from Ajinomoto Co. Inc. Aqueous solutions containing arginine was prepared in $10 \mathrm{mM}$ citric acid. The $\mathrm{pH}$ was adjusted with $\mathrm{HCl} ; 10 \mathrm{mM}$ citric acid was insufficient to titrate arginine. The $\mathrm{pH}$ meter was routinely calibrated using $\mathrm{pH}$ calibration standards.

Cells and viruses. Vero cells were grown in Eagle's minimum essential medium (MEM) containing 5\% fetal bovine serum. Herpes simplex virus type 2, strain 186 (HSV-2) was used throughout the experiments. The viruses were propagated in Vero cells in MEM supplemented with $0.5 \%$ fetal bovine serum and stored at $-80^{\circ} \mathrm{C}$ until use. The amount of virus was measured by a plaque assay on Vero cells as described previously (14).

Assay for virucidal activity. All the starting materials were stored on ice prior to the virus inactivation experiments. An excess volume of solvents was mixed with the virus stock so that the concentration and $\mathrm{pH}$ would not be affected: i.e., a $290 \mu 1$ of the solvents containing different concentrations of arginine or $\mathrm{NaCl}$ to be tested received $10 \mu \mathrm{l}$ of virus 

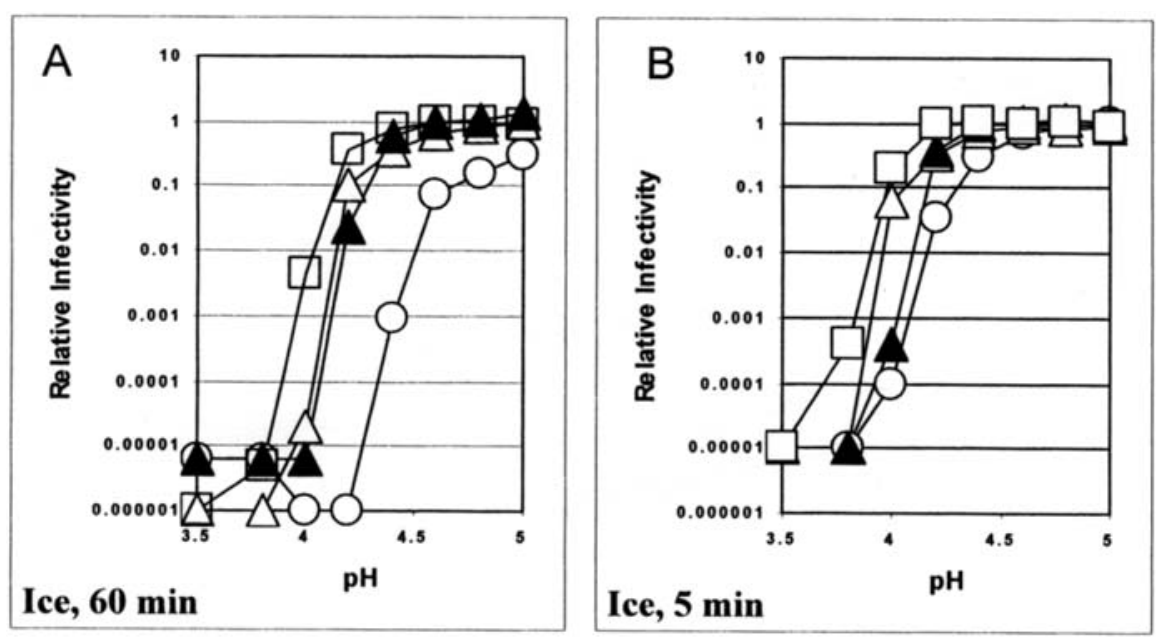

Figure 1. Inactivation of HSV-2 on ice as a function of $\mathrm{pH}$. The virus was incubated with an excess volume of solvents on ice for 60 min (A) or 5 min (B). Number of infectious virus was determined by a plaque assay after the incubation. $\triangle, 0.1 \mathrm{M}$ citrate; $\bigcirc, 0.7 \mathrm{M}$ arginine; $\Delta, 0.1 \mathrm{M}$ citrate plus $0.6 \mathrm{M} \mathrm{NaCl}$; $\square, 0.7 \mathrm{M}$ citrate.

preparations $\left[\sim 10^{8}\right.$ plaque-forming units $\left.(\mathrm{PFU}) / \mathrm{ml}\right]$. This virus preparation was incubated at the indicated temperature for 5 or $60 \mathrm{~min}$. After incubation, aliquots of these virus samples were 100-fold diluted with ice-cold Dulbecco's phosphate-buffered saline (PBS) without $\mathrm{Ca}^{2+}$ and $\mathrm{Mg}^{2+}$ containing $1 \%$ calf serum. The viruses were further diluted with PBS containing $1 \%$ calf serum and the number of infectious virus in the treated preparation was measured by a plaque assay. There was little virus inactivation in PBS and hence the amount of infectious virus in PBS was close to constant.

\section{Results and Discussion}

As a pH titration control solvent, $0.1 \mathrm{M}$ citrate was used. This is a common solvent used to titrate the protein solution for the purpose of the virus inactivation. Acid titration curve of HSV-2 incubated on ice for $60 \mathrm{~min}$ is shown in Fig. 1A (open triangle). A slight, but significant degree of the virus inactivation occurred between $\mathrm{pH} 4.2$ and 4.6. There is $\sim 80 \%$ reduction in virus yield, a significant number in normal scale, but not in the Log scale (as plotted in Fig. 1A). A sharp decrease in the virus yield was observed below $\mathrm{pH}$ 4.2. In fact, there was 5-Log reduction at $\mathrm{pH} 4.0$ and undetectable virus yield at $\mathrm{pH} 3.8$. Thus, the virus infectivity decreases by more than 4- $\mathrm{Log}$ within a $\mathrm{pH}$ unit of 0.4 (4.2-3.8). This is most likely due to titration of carboxyl groups on viral proteins that generates positively charged surface of virus particles and, as a consequence, leads to irreversible damage in the viruses.

Similarly, a slight virus inactivation occurred in the presence of $0.7 \mathrm{M}$ arginine, but at a slightly higher $\mathrm{pH}$; i.e., about $1-\log$ reduction in virus infectivity was observed between $\mathrm{pH} 4.6$ and 5.0 (Fig. 1A, open circle), about $0.4 \mathrm{pH}$ unit higher than in $0.1 \mathrm{M}$ citrate. Below $\mathrm{pH} 4.6$, a sharp decrease in the virus yield was observed, leading to an over 5- $\log$ reduction at $\mathrm{pH} 4.2$. At this $\mathrm{pH}$, the effect of $0.1 \mathrm{M}$ citrate was less than 1-Log reduction, indicating over 4-Log difference in the ability to kill virus between $0.1 \mathrm{M}$ citrate and $0.7 \mathrm{M}$ arginine at $\mathrm{pH}$ 4.2. In addition, 6-Log reduction was achieved at $\mathrm{pH} 3.8$ by $0.1 \mathrm{M}$ citrate, which was $0.4 \mathrm{pH}$ unit lower than $0.7 \mathrm{M}$ arginine. It is thus evident that $0.7 \mathrm{M}$ arginine synergizes with acidic $\mathrm{pH}$ for inactivating $\mathrm{HSV}-2$. It should be noted that $0.7 \mathrm{M}$ arginine alone has little virus inactivation effects above $\mathrm{pH} 5.0$ on ice.

Arginine is a monovalent or divalent cation depending on the $\mathrm{pH}$. Therefore, it is possible that higher ionic strength of $0.7 \mathrm{M}$ arginine contributed to the observed stronger virus inactivation by this solvent. The addition of $0.6 \mathrm{M} \mathrm{NaCl}$ to $0.1 \mathrm{M}$ citrate resulted in little change in the virus inactivation (compare solid triangle with open triangle), suggesting that the ionic strength plays little role in the virus inactivation: two curves nearly overlap with each other as shown in Fig. 1. Increasing citrate concentration to $0.7 \mathrm{M}$ and resultant higher ionic strength showed weaker virus inactivation than $0.1 \mathrm{M}$ citrate, as the $\mathrm{pH}$ titration curve shifted to lower $\mathrm{pH}$ for $0.7 \mathrm{M}$ citrate. For example, reduction in the virus infectivity was $60 \%$ by $0.7 \mathrm{M}$ citrate and $90 \%$ in $0.1 \mathrm{M}$ citrate at $\mathrm{pH} 4.2$, or more than 4-Log reduction occurred at $\mathrm{pH} 4.0$ in $0.1 \mathrm{M}$ citrate while the same degree of reduction occurred at approximately $\mathrm{pH}$ 3.85 in $0.7 \mathrm{M}$ citrate. Thus, it is clear that $0.7 \mathrm{M}$ citrate has lower virus inactivation potency than $0.1 \mathrm{M}$ citrate with and without $0.6 \mathrm{M} \mathrm{NaCl}$.

Above conditions, i.e., 60-min exposure to the solvent on ice, is far from the condition that can be used for in vivo application of arginine solution. Both acidic $\mathrm{pH}$ and arginine concentration may not be maintained that long due to secretion of body fluid. Therefore, we next examined the effects of temperature for a shorter exposure time of $5 \mathrm{~min}$. As a starting point, the effects of 5-min exposure on ice are shown in Fig. 1B. It is apparent that the $\mathrm{pH}$ titration curve is shifted to lower $\mathrm{pH}$ for the 5-min exposure than the 60-min incubation. This resulted in decrease in $\mathrm{pH}$ required for 4-Log reduction in virus yield; i.e., $\sim 0.2$ unit lower $\mathrm{pH}$ was required to achieve the same level of virus inactivation when the incubation time one ice was reduced from 60 to $5 \mathrm{~min}$; namely, 

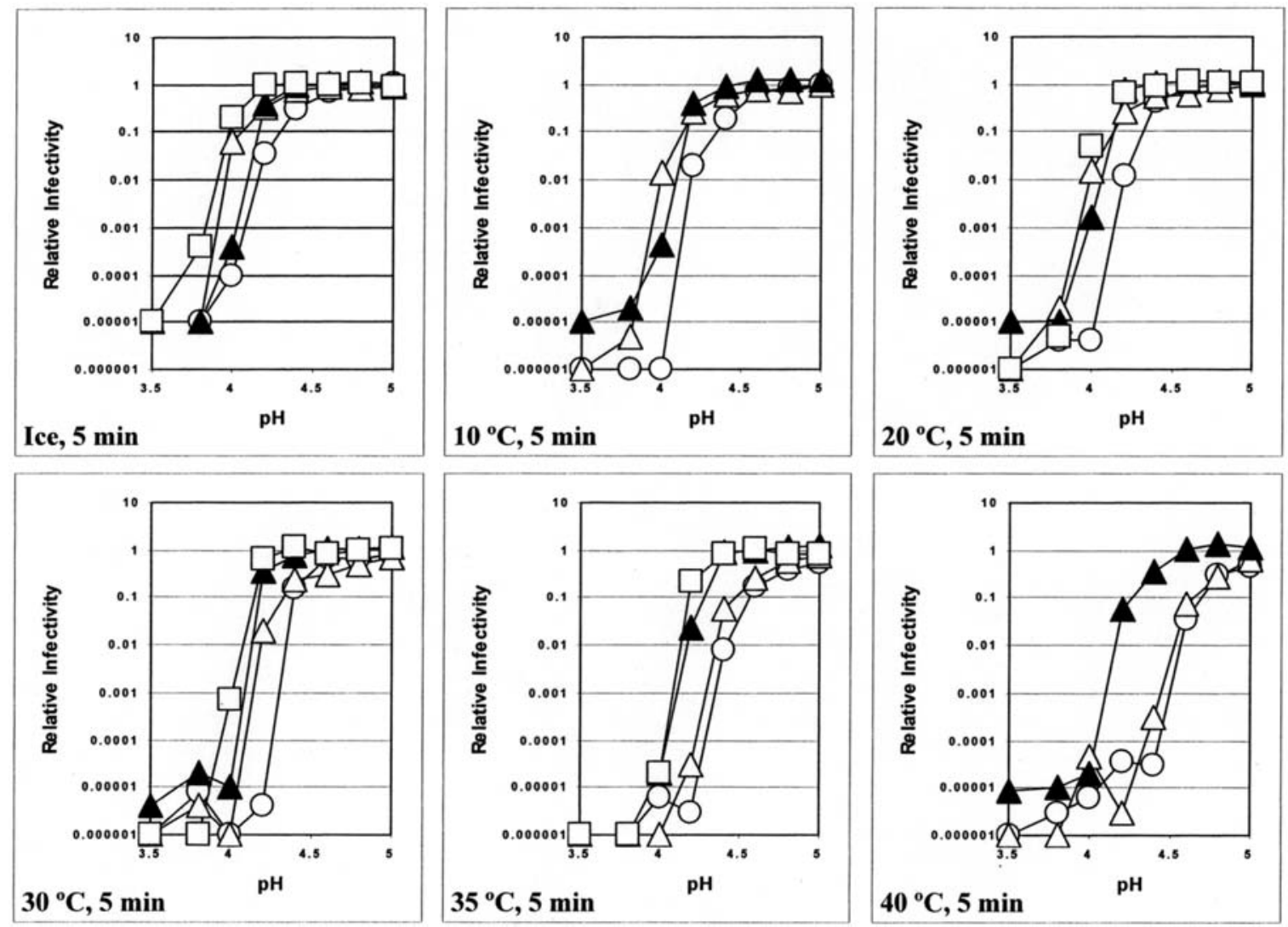

Figure 2. Inactivation of HSV-2 at different temperature. The virus was incubated with an excess volume of solvents for 5 min at various temperature. Number of infectious virus was determined by a plaque assay after the incubation. $\triangle, 0.1 \mathrm{M}$ citrate; $\bigcirc, 0.7 \mathrm{M}$ arginine; $\Delta, 0.1 \mathrm{M}$ citrate plus $0.6 \mathrm{M} \mathrm{NaCl}$; $\square, 0.7 \mathrm{M}$ citrate.

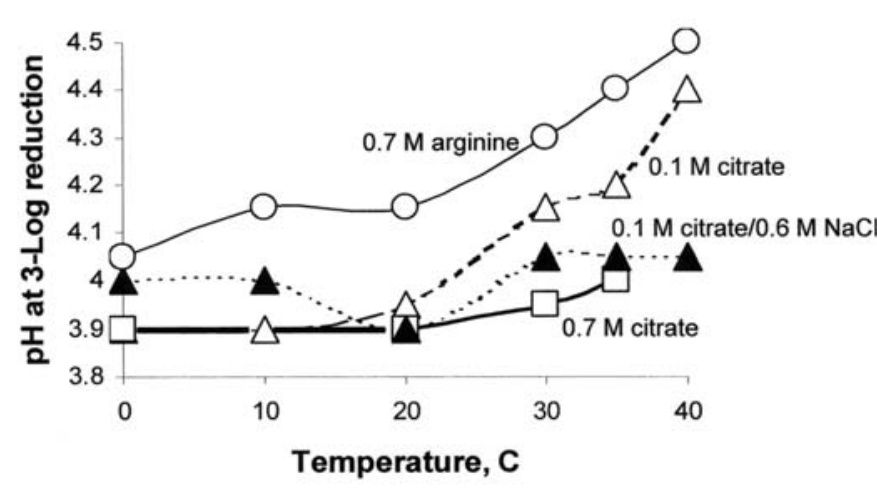

Figure 3. Plot of the $\mathrm{pH}$ that shows 3-Log reduction as a function of temperature.

reducing the incubation time from 60 to 5 min resulted in decreased the virus inactivation.

Increasing temperature enhanced the virus inactivation as shown in Fig. 2 (from upper left corner to lower right corner, on ice, $10,20,30,35$ and $40^{\circ} \mathrm{C}$ ), in which some temperature sets have no data for $0.7 \mathrm{M}$ citrate. Comparison of these panels indicate that as the temperature was increased, the $\mathrm{pH}$ titration curve for each solvent shifted to higher $\mathrm{pH}$, meaning that the same degree of virus inactivation can be achieved at higher $\mathrm{pH}$ when higher incubation temperature was used. Glancing through the data, it is evident that at any temperature the $\mathrm{pH}$ titration curve of $0.7 \mathrm{M}$ arginine showed the highest $\mathrm{pH}$ and $0.7 \mathrm{M}$ citrate showed the lowest, demonstrating that arginine is most effective and $0.7 \mathrm{M}$ citrate is least effective at any temperature. It appears that at low temperature the addition of $0.6 \mathrm{M} \mathrm{NaCl}$ appears to enhance the effect of $0.1 \mathrm{M}$ citrate, while it is opposite at higher temperature (compare the open triangle with the solid triangle at each panel). Thus, at higher temperature the addition of $0.6 \mathrm{M} \mathrm{NaCl}$ apparently suppressed the virus inactivation by $0.1 \mathrm{M}$ citrate. It is also evident that at higher temperature the effects of $0.1 \mathrm{M}$ citrate approach the level of virus inactivation obtained by $0.7 \mathrm{M}$ arginine (see Fig. 2, 35 and $40^{\circ} \mathrm{C}$ ).

The effects of temperature for each solvent are more clearly seen in Figs. 3 and 4. Fig. 3 shows the pH required to achieve 3-Log reduction at different temperature for each solvent. In this plot, the higher the $\mathrm{pH}$, the stronger the solvent is in the virus inactivation. It is thus expected that the effective virus inactivation $\mathrm{pH}$ for each solvent increases with the temperature. It appears that the $\mathrm{pH}$ that causes 3-Log reduction in $0.1 \mathrm{M}$ citrate is relatively constant at 3.9 between 0 and $20^{\circ} \mathrm{C}$ and sharply increases above $20^{\circ} \mathrm{C}$ from 3.9 at $20^{\circ} \mathrm{C}$ to 4.4 at $40^{\circ} \mathrm{C}$ (open triangle). At $0^{\circ} \mathrm{C}$, the addition of $0.6 \mathrm{M} \mathrm{NaCl}$ increased the $\mathrm{pH}$ from 3.9 to 4.0 (solid triangle), meaning that the addition of $\mathrm{NaCl}$ enhanced virus inactivation, as described in Fig. 2. It is interesting that in the presence of $0.6 \mathrm{M} \mathrm{NaCl}$, the $\mathrm{pH}$ decreases with temperature from 4.0 at 


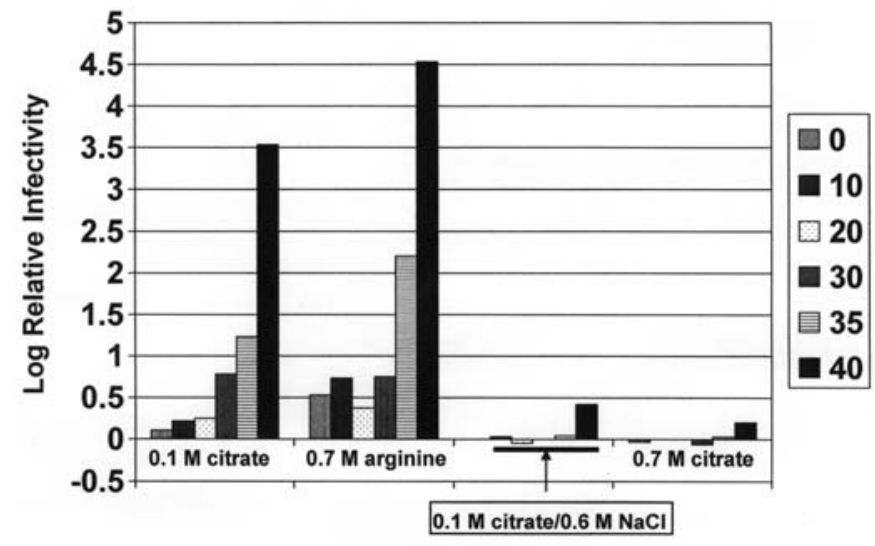

Figure 4. Plot of Log reduction value at $\mathrm{pH} 4.4$ for each solvent as a function of temperature.

$0^{\circ} \mathrm{C}$ to 3.9 at $20^{\circ} \mathrm{C}$, meaning that increase in temperature actually reduces the virus inactivation effects of $0.1 \mathrm{M}$ citrate plus $0.6 \mathrm{M} \mathrm{NaCl}$. In other words, it appears that temperature increase suppresses the effects of the solvent. Above $20^{\circ} \mathrm{C}$, increase in the $\mathrm{pH}$ is modest for this solvent, indicating that there is not much dependence of the effect of this solvent on temperature. The $\mathrm{pH}$ increased only to 4.05 at $40^{\circ} \mathrm{C}$. The effect of temperature on the virus inactivation by $0.7 \mathrm{M}$ citrate is small from 3.9 at $0^{\circ} \mathrm{C}$ to 3.95 at $30^{\circ} \mathrm{C}$. Conversely, the $\mathrm{pH}$ is consistently higher for $0.7 \mathrm{M}$ arginine than other solvents at any temperature. The $\mathrm{pH}$ increased from 3.95 at $0^{\circ} \mathrm{C}$ to 4.5 at $40^{\circ} \mathrm{C}$. As shown in Fig. 3, however, the $\mathrm{pH}$ becomes similar to that achieved by $0.1 \mathrm{M}$ citrate at $40^{\circ} \mathrm{C}$, meaning that, at such high incubation temperature, $0.1 \mathrm{M}$ citrate is nearly equally effective to $0.7 \mathrm{M}$ arginine.

Fig. 4 shows the Log reduction value at $\mathrm{pH} 4.4$ as a function of temperature for each solvent. At this $\mathrm{pH}, 0.1 \mathrm{M}$ citrate has little inactivation effect up to $20^{\circ} \mathrm{C}$, above which Log reduction value sharply increases to 3.5 at $40^{\circ} \mathrm{C}$. The trend is similar with $0.7 \mathrm{M}$ arginine, except that this solvent has $\sim 10$-fold higher potency than $0.1 \mathrm{M}$ citrate at 35 and $40^{\circ} \mathrm{C}$. Conversely, the addition of $0.6 \mathrm{M} \mathrm{NaCl}$ or $0.6 \mathrm{M}$ citrate to $0.1 \mathrm{M}$ citrate suppressed the potency of $0.1 \mathrm{M}$ citrate at higher temperature, as shown by Log reduction value of nearly 0 even at $35-40^{\circ} \mathrm{C}$.

Proteins undergo acid-induced conformational changes or structure destabilization. Figs. 3 and 4 show that $0.1 \mathrm{M}$ citrate and elevated temperature induce destabilization of virus particles, resulting in irreversible inactivation, most likely reflecting conformational changes of viral proteins, although the effects on other viral components and their interactions cannot be excluded. Arginine at $0.7 \mathrm{M}$ enhances such destabilization, as seen in the increased virus inactivation, which can be explained from its salting-in effects $(4,7,15,16)$. Namely, arginine does appear to synergize with low $\mathrm{pH}$ and elevated temperature to enhance conformational changes of the viral proteins. On the contrary, higher citrate concentration or the addition of $0.6 \mathrm{M} \mathrm{NaCl}$ offsets the destabilization effects of low $\mathrm{pH}$, resulting in stabilization of the virus. This can be explained from the stabilizing and salting-out effects of citrate and $\mathrm{NaCl}(17-19)$.

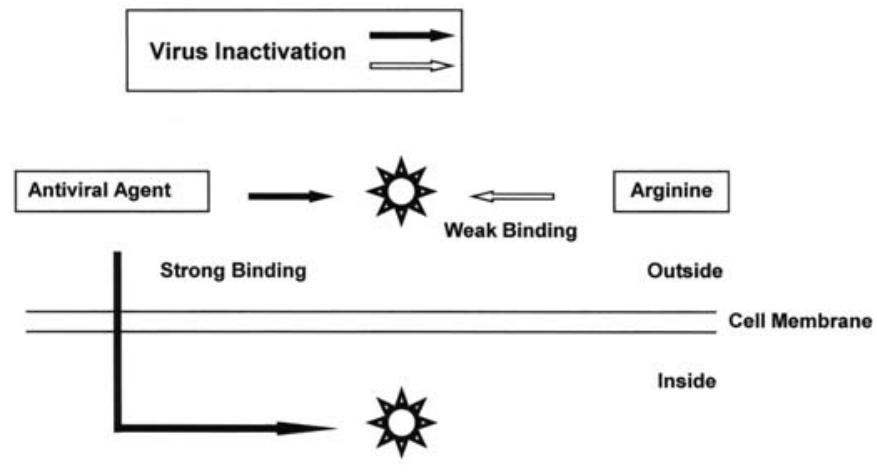

Figure 5. Schematic illustration of virucidal effects of antiviral/virucidal agent and arginine.

We have shown here and before that arginine-containing solvents synergize with $\mathrm{pH}$ and temperature for virus inactivation (9-11). Such enhanced virus inactivation by acidic arginine may be used to inactivate viruses for pharmaceutical proteins. Considering the established safety of arginine in human use, the observed inactivation of HSV-2, which causes superficial genital herpetic infections (13), may find potential topical applications. Namely, there is high degree of HSV-2 inactivation at $30^{\circ} \mathrm{C}$ or higher temperature, close to body surface temperature, in mildly acidic arginine solution of $\mathrm{pH}$ 4.0-4.5. Such solvent conditions may be sufficient to kill viruses at the site of superficial infections. A preliminary study showed that acidic arginine solution resulted in significant suppression of epithelial keratitis caused by herpes simplex virus type 1 infection in the rabbit eye model (Naito et al, unpublished data).

Certain antiviral agents, e.g., phenoxazine derivatives (20) and gallate derivatives (21), can directly inactivate viruses (13), as does arginine or detergent/solvent wash. These antiviral agents exert virucidal effects at $\sim \mu \mathrm{M}$ range, $\sim 10^{6}$-fold lower concentrations than the effective arginine concentration of 0.3-1.0 M (10-12, this study). The observed difference in effective concentration reflects difference in affinity for their target sites (see Fig. 5 for schematic illustration). Regardless of which viral components arginine binds, it has much lower affinity. On the contrary, the antiviral/ virucidal agents have much higher affinity for their target sites. Such a high affinity binding, while leading to a strong virus inactivation at low concentrations, has some disadvantages, including generation of drug-resistant viruses and cell toxicities. Intrinsic to high affinity is the specific binding of the antiviral drugs, a main cause of drug-resistant viruses. Due to their hydrophobic properties, they readily penetrate the cell membrane (Fig. 5) and may interfere with certain cellular metabolic processes, a potential cause of cell toxicities. Conversely, arginine weakly interacts with viruses, leading to irreversible virus inactivation, but such a weak binding to cells, when applied in vivo, is most likely reversible and hence less toxic. More importantly, weak binding is reflected on non-specific binding, meaning that arginine may bind to and damage multiple sites on viruses. Such multiple actions of arginine-induced virus inactivation are unlikely to generate arginine-resistant viruses, as it would require mutations of excessively large number of genes. 


\section{References}

1. Preuss T, Kamstrup S, Kyvsgaard NC, Nansen P, Miller A and Lei JC: Comparison of two different methods for inactivation of viruses I serum. Clin Diagn Lab Immunol 4: 504-508, 1997.

2. Brorson $\mathrm{K}$ and Norling L: Current and future approaches to ensure the viral safety of biopharmaceuticals. Dev Biol 118: 17-29, 2004.

3. Lee JC and Timasheff SN: Partial specific volumes and interactions with solvent components of proteins in guanidine hydrochloride. Biochemistry 13: 257-265, 1974.

4. Kita Y, Arakawa T, Lin TY and Timasheff SN: Contribution of the surface free energy perturbation to protein-solvent interactions. Biochemistry 33: 15178-15189, 1994.

5. Gekko K and Timasheff SN: Mechanism of protein stabilization by glycerol: preferential hydration in glycerol-water mixtures. Biochemistry 20: 4667-4676, 1981.

6. Schellman JA: Selective binding and solvent denaturation. Biopolymers 26: 549-559, 1987.

7. Arakawa T, Ejima D, Tsumoto K, Obeyama N, Tanaka Y, Kita Y and Timasheff SN: Suppression of protein interactions by arginine: a proposed mechanism of the arginine effects. Biophys Chem 127: 1-8, 2007.

8. Arakawa T, Kita Y and Timasheff SN: Protein precipitation and denaturation by dimethyl sulfoxide. Biophys Chem 131: 62-70, 2007.

9. Yamasaki H, Tsujimoto K, Koyama AH, Ejima D and Arakawa T: Arginine facilitates inactivation of enveloped viruses. J Pharm Sci 97: 3067-3073, 2008.

10. Katsuyama Y, Yamasaki H, Tsujimoto K, Koyama AH, Ejima D and Arakawa T: Butyroyl-arginine as a potent virus inactivation agent. Int J Pharm 361: 92-98, 2008

11. Utsunomiya H, Ichinose M, Tsujimoto K, Katsuyama Y, Yamasaki H, Koyama AH, Ejima D and Arakawa T: Co-operative thermal inactivation of herpes simplex virus and influenza virus by arginine and $\mathrm{NaCl}$. Int J Pharm 366: 99-102, 2009.
12. Arakawa T, Kita Y and Koyama AH: Synergistic virus inactivation effects of arginine. Biotech J 4: 174-178, 2009.

13. Keller MJ, Tuyama A, Carlucci MJ and Herold BC: Topical microbicides for the prevention of genital herpes infection. J Antimicrob Chemother 55: 420-423, 2005.

14. Koyama AH and Uchida T: The effect of ammonium chloride on the multiplication of herpes simplex virus type 1 in Vero cells. Virus Res 13: 271-282, 1989.

15. Tsumoto K, Ejima D, Kita Y and Arakawa T: Review: why is arginine effective in suppressing aggregation? Protein Pept Lett 12: 613-619, 2005.

16. Arakawa $\mathrm{T}$ and Tsumoto $\mathrm{K}$ : The effects of argnine on refolding of aggregated proteins: not facilitate refolding, but suppress aggregation. Biochem Biophys Res Commun 304: 148-152, 2003.

17. Hegardt FG and Pié A: Sodium citrate salting-out of the human blood serum proteins. Rev Esp Fisiol 24: 161-168, 1968.

18. Arakawa T and Timasheff SN: Preferential interactions of proteins with salts in concentrated solutions. Biochemistry 21: 6545-6552, 1982.

19. Kaushik JK and Bhat R: A mechanistic analysis of the increase in the thermal stability of proteins in aqueous carboxylic acid salt solutions. Protein Sci 8: 222-233, 1999.

20. Hayashi K, Hayashi T and Tomoda A: Phenoxazine derivatives inactivate human cytomegalovirus, herpes simplex virus-1, and herpes simplex virus-2 in vitro. J Pharmacol Sci 106: 369-375, 2008.

21. Kratz JM, Andrighetti-Fröhner CR, Leal PC, Nunes RJ, Yunes RA, Trybala E, Bergström T, Barardi CRM and Simöes CMO: Evaluation of anti-HSV-2 activity of gallic acid and pentyl gallate. Biol Pharm Bull 31: 903-907, 2008. 